Bovsh Liudmyla, $\mathrm{PhD}$ in Economics, Associate Professor, Kyiv National University of Trade and Economics, Kyiv, Ukraine ORCID:0000-0001-6044-3004, ResearcherID: O-4222-2016

Hopkalo Larysa, $\mathrm{PhD}$ in Economics, Associate Professor, Kyiv National University of Trade and Economics, Kyiv, Ukraine ORCID: 0000-0003-3513-0502, ResearcherID: N-8833-2016

\title{
COMPLIANCE QUALITY THE LUXURY HOTEL SERVICE
}

In the article reflects the directions of compliance of the hotel services quality with standards quality and consumer needs. Stated that the hotel in the luxury segment should take into account the requirements of national and local legislation, and in the planning of activities to lean on psychophysical needs and demand of potential consumers.

Keywords: hotel service, compliance quality, luxury hotel.

Бовщ Людмила, Гопкало Лариса. Комплаєнс якості послуг лакшеріготелів.

У статті відображено напрями комплаєнсу якості готельних послуг стандартам якості та потребам споживачів. Зазначено, що готель у сегменті лакшері повинен враховувати вимоги національного та місцевого законодавства, а в плануванні діяльності спиратися на психофізичні потреби та попит потенційних споживачів.

Ключові слова: готельне обслуговування, комплаєнс якості, лакшеріготель.

Relevance of the research topic. The modern world is characterized by the rapid dynamics of technology, which increases the consciousness of consumers, saturates with new trends that is caused by socio-psychological and economic transformations of society. Each era of civilization has its own cross-cultural and cross-technological needs, worldviews and reactions to marketing influence. Research 
and consideration of these features in the strategic perspective of economic subject activates appearance and development of adequate for trends formats of business, reduces compliance risks. In addition, the growth of leisure time and the pursuit of new emotions and experiences encourage people to rest and travel, organization of which is based on accommodation and food that is often the aim of the visit. Therefore, the quality requirements of hotel and restaurant services must be constantly updated, which causes verification of the range of hotel services to the level of service and compliance control.

Formulation of the problem. In terms of positioning the hotel as an indicator of social growth is becoming more urgent development of national standards that would regulate the level of service in luxury-segmented hotels. Proof of this is the geography proliferation of international hotel operators in the hotel market in Ukraine.

Development of modern legal and regulatory instruments of hotel management today must be based on economic and social needs of potential customers. The compliance of the regulatory base for standardization and certification of hotel entities should reflect the global trends of qualitative changes and psychophysical features of the recipient of hotel services.The most economically active generation today is the generation of so-called millennials, who make over $53 \%$ of their bookings and purchases online. Moreover, for them important aspects of the selection are unique products that provide positioning and comfort. Therefore, investment interest should contact segment luxury, which has positive forecasts: an annual revenue growth $-4.5 \%$; by 2024 , the world market size will reach 22.2 million dollars(Global Luxury Hotel Market Analysis, 2019). In particular, the prospects of the domestic market are quite significant in view of the tourism potential in the implementation of luxury service projects.

The above-indicated justifies the urgency of studying the needs of tourists, existing hotel business concepts of Ukraine, and the formation of a national system of classification of hotel services in the luxury segment.

Analysis of recent research and publications. Research on the questions of quality of hotel services is always relevant, because the main focus is pointed to safety and comfort for travelers.Service quality compliance has been the subject of research by many foreign scholars (Asad Mohsin, 2010; Batinić Ivica, 2016; Boon-Liat, C., Zabid, A. R., 2013; Carol Lu, 2014; Gil, S. M., Hudson, S., Quintana, T., 2006; Khalid Saleh Al-Rashid, 2014; Mukhles M. Al-Ababneh, 2017; Najafi S., Saati S., Tavana M., 2015; Salszar A., Costa J., Rita P.,2010; Sharma A., Sharma K., 2017 and others. However, luxury service was only considered as a component of the service system.Due to its isolation as a separate segment in the hospitality industry, it is worth exploring and evaluating aspects of the quality of luxury services through the light of socio-economic paradigms of comfort, quality and luxury.

Presenting main material. The growth of international activity in the diplomatic business area and in tourism promotes to the growth of the luxury hotel 
market worldwide: today most business meetings and events are organized and accompanied by hotels. On the other hand, a restless daily lifestyle influences on consumers' desire to spend their free time in order to experience a luxurious life, get services that include a high level of security, exquisite interior design, high-quality restaurant service, innovative SPA procedures, everything that not only satisfies the needs of hotel guests, but also emphasizes their status, creates new impressions. The demanding consumer seeks for attentive attention, taking into account the individuality and possibility of evaluating the quality of the services with appropriate response of the hotel.In the product service hotel take into account national peculiarities, mental characteristics and age predisposition it is hard enough, but possible. The national classification system for luxury hotels should be based on the development of a marketing complex that meets customer expectations, in particular quality of service.

Compliancestandards of luxury services should be based on the concept of «4 channels» by F. Schulz von Tuna, which describes the multilevel nature of messages in the communication system [F. Schulz von Tuna,2008] (Fig. 1).

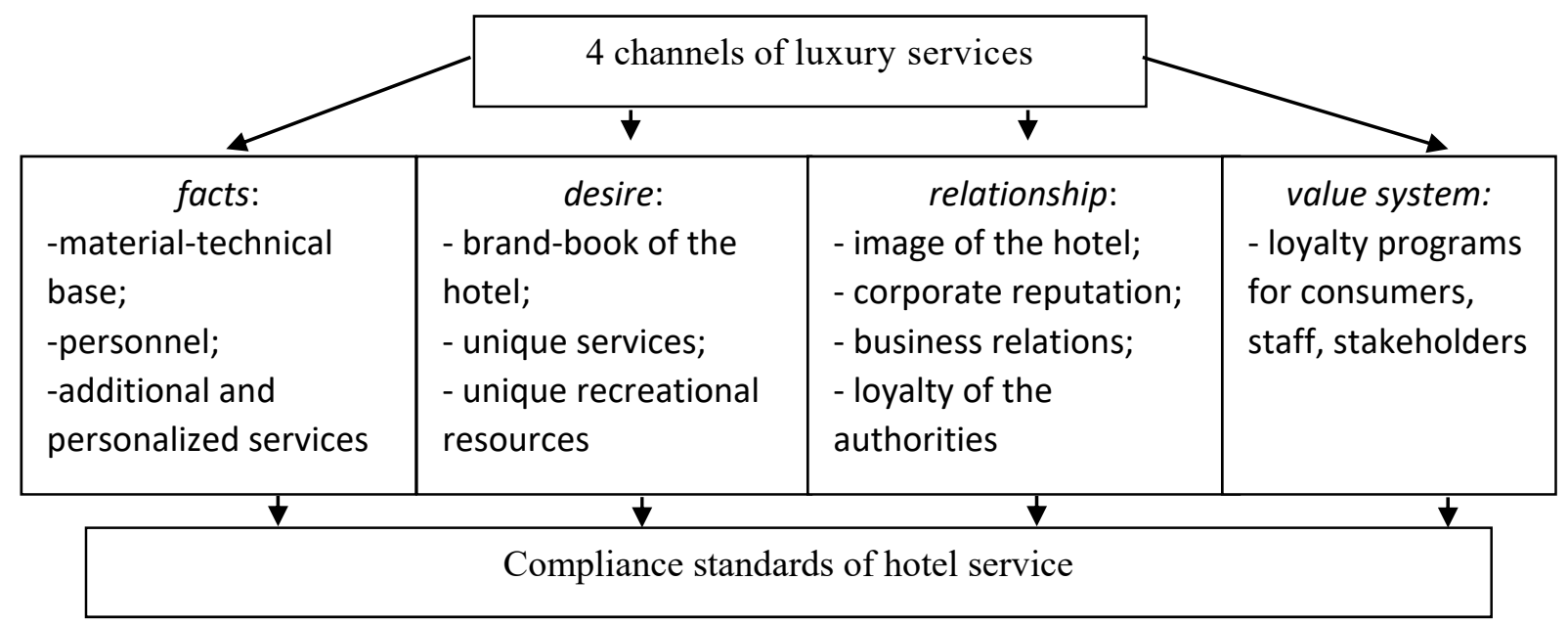

Fig. 1. Channels of luxury servise

Source: own development byMukhles M Al-Ababneh, Schulz von Thun

Fact Channel: It is important for luxury segment customers to create service packages that save time and simplify business and personal issues. Therefore, the package offers should be in the focus of hotel marketing and demonstrate successful experience.

Inturn, thedesire: manipulationandmotivationtochoosemustbemadewhenusing the full toolkit of marketing influence with a personalized approach.

Therefore, presentation materials should give a clear idea and desire to buy a hotel product. Traditional loyalty systems in the luxury segment are almost out of service.Therefore, loyalty systems should have a customer-based approach and be based on the corporate reputation of the hotel and its services. The value system, that takes into account the compliance control of the quality of hotel services should exist at all levels of management and organization of the enterprises - fromthe specific employee and the 
department to the hotel as a whole. Corporate reputation and culture are becoming a brand.

Implemented channels in the compliance system determine the legitimacy of the actions of the hotel subject as a whole and its every worker: from top management to all employees of the units. Counterparties and consumers take compliance management as conformity with legal requirements, proposed rules, hotel standards, and contract terms. The implementation of complex controls is also an important issue for international hotel operators, who must maintain compliance with relevant local law.

Therefore, in the luxury segment, the formation of package offers for guests must comply with market trends and tendencies, as well as comply with regulations and legislation.

In characterizing the economically active social groups modified emerging needs and tastes, which demand new marketing strategies and approaches to the development of concepts of quality. Among the peculiarities of the potential demand is conditional separation of target audiences in Generation X (Generation 13), Y (Millenials), Z (Homeland Generation) and $\alpha$ (Emotional intelligence Generation) (Table 1).

Table 1

\section{Marketing peculiarities of market segments according to the theory of generations}

\begin{tabular}{|c|c|c|c|}
\hline Generation & Values & Needs & The tool of influence \\
\hline $\begin{array}{c}\text { X } \\
\text { (conditionally 1965- } \\
\text { 1982 years of birth) }\end{array}$ & comfort and nostalgia & need to choose & $\begin{array}{l}\text { strengthen the sense of } \\
\text { unique, providing } \\
\text { benefits activation } \\
\text { retrospective feelings }\end{array}$ \\
\hline $\begin{array}{c}\text { Y } \\
\text { (conditionally1983- } \\
\text { 1992years of birth) }\end{array}$ & $\begin{array}{l}\text { overstated self-esteem, } \\
\text { expectations and } \\
\text { vulnerability }\end{array}$ & $\begin{array}{l}\text { expectations must } \\
\text { coincide with reality, } \\
\text { the product must be } \\
\text { known, fashionable }\end{array}$ & $\begin{array}{l}\text { reviews, infographics, } \\
\text { concentrated } \\
\text { presentations, } \\
\text { unconventional } \\
\text { marketing methods }\end{array}$ \\
\hline $\begin{array}{c}\mathrm{Z} \\
\text { (conditionally1992- } \\
2010 \text { years of birth) }\end{array}$ & $\begin{array}{l}\text { high speed of } \\
\text { information perception }\end{array}$ & $\begin{array}{l}\text { unique and impressive } \\
\text { characteristics of the } \\
\text { product (service), } \\
\text { opportunities, gives } \\
\text { status, style, } \\
\text { environmental } \\
\text { friendliness }\end{array}$ & $\begin{array}{l}\text { technologies of the } \\
\text { future, visual content, } \\
\text { videos, infographics, } \\
\text { short help, etc. }\end{array}$ \\
\hline $\begin{array}{c}\alpha \\
\text { (conditionally after } \\
2010 \text { pоку year of } \\
\text { birth) }\end{array}$ & $\begin{array}{l}\text { personal space, time } \\
\text { management, saturation } \\
\text { digital technology }\end{array}$ & $\begin{array}{l}\text { Object / subjectv } \\
\text { reputation, } \\
\text { personification of } \\
\text { services, home } \\
\text { minimalism, } \\
\text { maximalism in devises }\end{array}$ & $\begin{array}{l}\text { Youtube, mobile apps, } \\
\text { social networks, video } \\
\text { content, etc. }\end{array}$ \\
\hline
\end{tabular}

Source: owndevelopmentbyAsad Mohsin, Boon-Liat, C., Zabid, A., Kuo, N. T., Reklamaster.com, Economictimes.indiatimes.com 
Comparing the characteristics of generations with a wide range of research, we can draw the following conclusions that determine the value of compliance-controlin consumer behavior studies of the luxury segment:

- in the first place in the generation $X$ - comfort, so the traditional luxury service is just for them;

- millennials $(\mathrm{Y})$ of ten spend money on travel that many consider to be a priority. Therefore, the quality of luxury services, supported by the brand, will be an effective argument for their choice of hotel;

- representatives of the generation $\mathrm{Z}$ value home comfort, environmental friendliness, ease and safety - therefore luxury-hotel must provide the product of status, authority. In this case, network hotel brands will be preferred;

- for generation $\alpha$ is decisive in choosing voice technology, emotion recognition technology and cognitive status, behavior prediction algorithms, chat-bots and virtual assistants, internet of things. SMART hotels, robot-waiters and robotconcierge, virtual informants should all be priorities in the generation of luxury service concepts for this generation.

As for the instruments of influence, it should be noted, also, significant transformation of perception and the decision to purchase in different generations. Yes, effective promotional messages have decreased from 3 minutes for Generation X to 6 seconds for Generation $Z$ and 1 second of content for Generation $\alpha$. As for communication channels, they have been transformed from radio, television to the internet, capable for quickly finding information and making simultaneous comparisons.

Synthesizing the above, we can notice the basic components of the hotel selection process - quality of service, safety and price, which are imperatives of the compliance control of luxury segment hotels.

In the segment of luxury hotels in Ukraine, as in the whole world, the largest share in the market belongs to 5 star business hotels. Business people, travel groups, small conference groups and individual tourists are the target customers of business hotels. To this category in Ukraine should be included SPA hotels, Resort \& Spa hotels. In addition, the airport hotel segment is showing strong growth in the luxury hotel market around the world, as the target customers of the airport hotels are airline passengers who mainly travel for leisure, search for new emotions and business clients.

Analysis of the material base and the list of services of enterprises to the group of hotels offering luxury-service in Ukraine, include the following: Fairmont Grand Hotel, Premier Palace Hotel, Riviera House, Grand Hotel Lviv Luxury \& Spa, Bankhotel in Lviv, Edem Resort Medical \& SPA, Radisson Blu Resort Bukovel, Rixos-Prykarpattya, Mirotel Resort \& SPA, M1 Club Hotel in Odessa, InterContinental Hotels Group PLC, Hyatt Regency Kyiv, Hilton Kyiv [Reuters.com, 2019]. Accordingly, the luxury hotels include both of autonomous and national chain hotels (Premier Palace Hotel, Reikartz). For defining the level of satisfaction of 
luxury-service in the hotels in Ukraine, there has been selected 26 enterprises from the general sample and divided into groups: $\mathrm{A}$ - hotels under management of the chain brands; $\mathrm{B}$ - hotels included in the national chain; $\mathrm{C}$ - independent hotels (Table 2).

Table 2

Average value of evaluated criteria of luxury-service in hotels of Ukraine

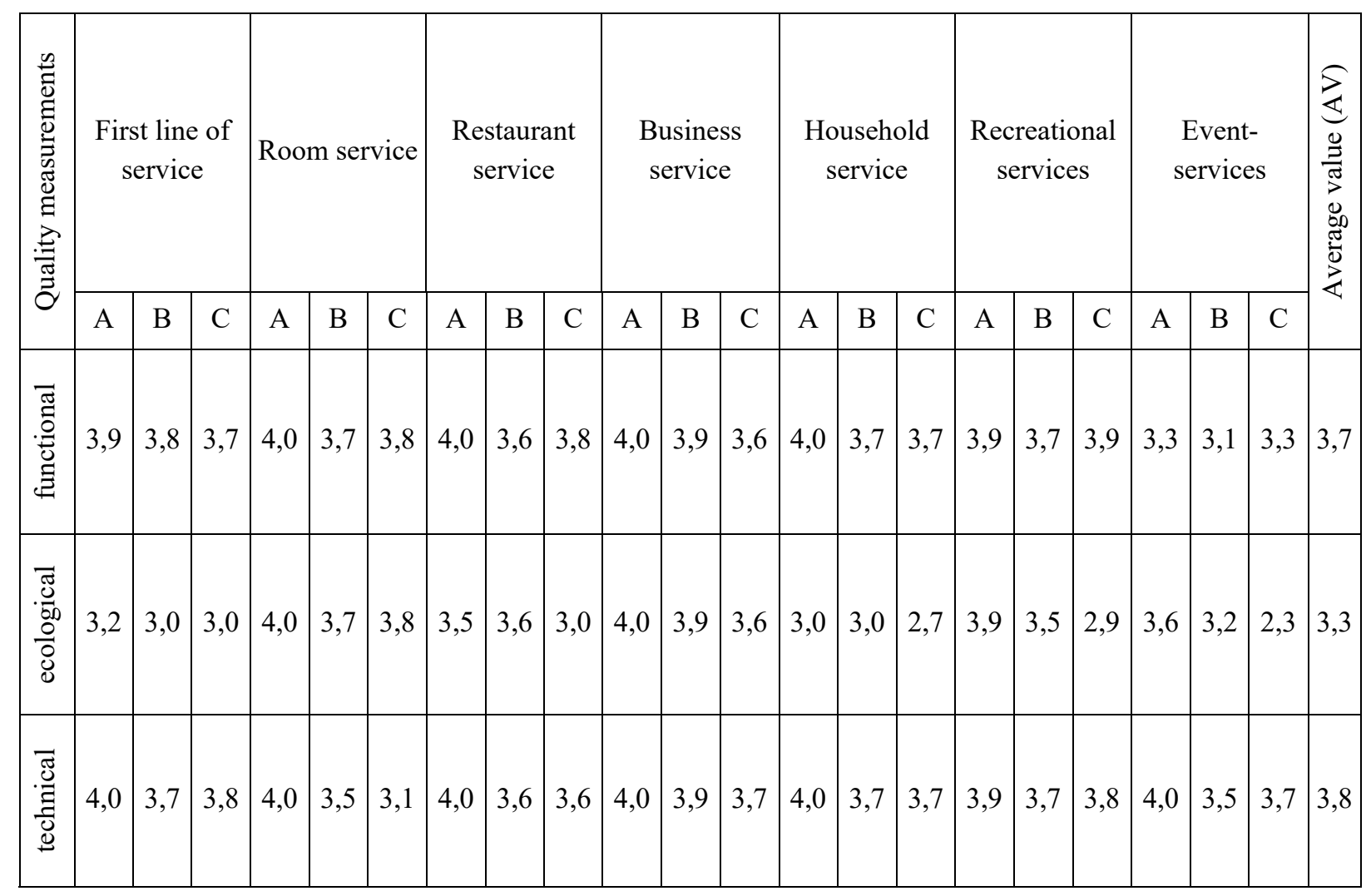

Source: owndevelopment

The evaluation of the degree of importance of the criteria was made in the process of conducting a field study of the defined the selection. So, the quality of luxury service consists three parameters: functional quality, ecological and technical quality, which are defined by the following tangibility: confidence, loyalty, sensitivity and promptness (a presence of the parameter - 1point, the absence - 0point. The maximum quantity of points -4 ).

The functional quality defines the ability of staff to perform their duties qualitatively and depends on the qualifications, experience, skills, professional skills of employees, embodies the useful properties of services and the characteristic features of the process of their providing of them. The technical quality defines the compliance of the requirements to the material and technical base. The ecological quality is formed using safe and ecological logistical concepts and Zero Waste principles. 
Monitority the quality of hotel services based on customer satisfaction (QCS) using the following formula 1:[Carol Lu, 2014;Garmider L.D., 2014;Gil, S., Hudson, S., Quintana, T., 2016]

$$
\mathrm{QCS}=(\mathrm{AV}-\mathrm{CSI}) \times \mathrm{M} / 10
$$

where CSI - consumer satisfaction index;

$\mathrm{AV}$ - the average of the criteria evaluated;

$\mathrm{M}$ - maximum quantity of points.

So, the average indicator of the quality index is 3,6; including: among the international chain brands 3,8; national chain - 3,5; autonomous hotels $-3,4$.

That's why we receive the following values of quality scores:

$$
\begin{aligned}
& \mathrm{QCS}_{\mathrm{A}}=(3,6-3,8) \times 4 / 10=-0,112 ; \\
& \mathrm{QCS}_{\mathrm{B}}=(3,6-3,5) \times 4 / 10=0,04 ; \\
& \mathrm{QCS}_{\mathrm{C}}=(3,6-3,4) \times 4 / 10=0,08 .
\end{aligned}
$$

Point the received values on the modified service positioning map of quality (Fig. 2). As a result of the research we have found out the degree of importance of the selected criteria of the quality level of luxury-service for certain groups of hotels which are located in the near range.

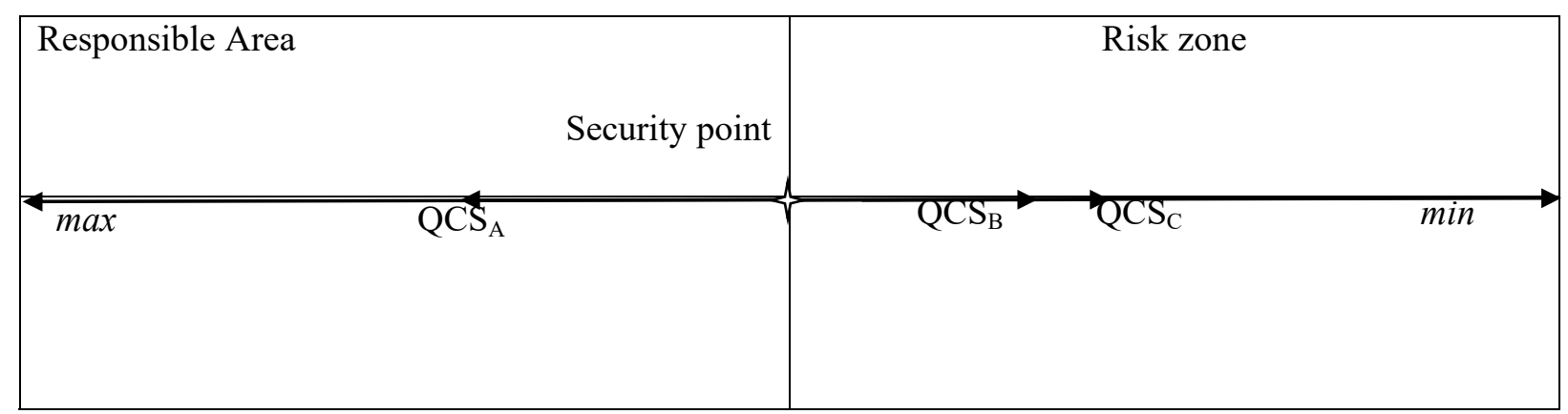

Fig. 2. Modifiedquality positioning map

Source: owndevelopment

For example, the functional quality of hotel security is estimated at $3,9-3,7$ points, ecological quality is evaluated at $3,2-3,0$ points, and technical one at $4,0-3,7$ points.

As we see from the modified service Positioning Map of Figure 1, there are three strategic attitude, when the impressions of with services quality and the level of 
consumer satisfaction exceed professional evaluations; risk-management - the quality level does not the full-fledged and safety point that fully correspondence of the expected and actual quality of services.Therefore, it's expected that in the area of responsible attitude there are the hotel chains for which quality and customer satisfaction are priorities of tasks of strategic management and development, the service system of which is based on the implementation of standards of service at the luxury level.

The national hotel operators and autonomous hotels which are positioning themselves as luxury hotels should implement the system of standards for organization and providing services, based on on the results of consumer market research and service technology trends, namely:

- Standards for individual safety of guests at luxury hotel.

- Standards for the organization of premises at luxury hotels.

- Standards of restaurant luxury service.

- Standards for the organization of business services at luxury hotels.

- Standards of household service at luxury hotels

- Standards of recreational service at luxury hotels.

- Animation service standards at luxury hotels.

Conclusion. From the above mentioned it follows that the compliance control of the quality of hotel services is an important task and purpose of management in the segment of luxury service. Getting a high level of quality of service and customer satisfaction is equal to increasing customer loyalty, increasing market share, increasing return on investment, reducing costs and guaranteeing competitive advantages in the luxury segment.

Further research needs to be deepened in terms of the impact of quality components of luxury hotel activity on the formation of its reputation.

\section{REFERENCES}

1. Asad Mohsin. Customer perceptions of service quality in luxury hotels in New Delhi, India: An exploratory study. International Journal of Contemporary Hospitality Management 22(2) March 2010. Retrieved from https://www.researchgate. net/publication/43438198_Customer_perceptions_of_service_quality_in_luxury_ hotels_in_New_Delhi_India_An_exploratory_study

2. Batinić Ivica. Hotel management and quality of hotel services. Journal of Process Management - New Technologies, International. Vol. 4, No.1, 2016. Retrieved from https://scindeks-clanci.ceon.rs/data/pdf/2334-735X/2016/2334735X1601025B.pdf 
3. Boon-Liat, C., Zabid, A. R. (2013). Service quality and the mediating effect of corporate image on the relationship between customer satisfaction and customer loyalty in the Malaysian hotel industry. International Journal of Business, 15, 99-112.

4. Carol Lu. Service quality and customer satisfaction: qualitative research implications for luxury hotels. Emeraldinsight. Retrieved from https://www. emeraldinsight.com/doi/abs/10.1108/IJCTHR-10-2014-0087?journal Code=ijcthr

5. Cronin J.J. Measuring Service Quality: A Reexamination and Extension / J.J. Cronin, S.A. Taylor // Journal of Marketing, 1992. Vol. 56. P. 55-68. Retrieved from https://www.researchgate.net/profile/J_Cronin_Jr/publication/ 225083621_ Measuring_Service_Quality_A_Reexamination_And_Extension/links/54fbd7a70cf20 700c5e7dc4c/Measuring-Service-Quality-A-Reexamination-And-Extension.pdf.

6. Evans J.R. The management and control of quality / Evans James R., Lindsay William M. $-5^{\text {th }}$ ed. - South-Western, a division of Tomson Learning, 2002. P. 838

7. Garmider L.D. Ocinka zadovolenosti zacikavlenyh storin u rozvytku kadrovogo potencialu torgovel'nyh pidpryjemstv / L.D. Garmider // Ekonomichnyj nobelivs'kyj visnyk 2014, V.1(7). - S. 108-112

7. Gil, S. M., Hudson, S., \& Quintana, T. A. (2006). The influence of service recovery and loyalty on perceived service quality: A study of hotel customers in Spain. Journal of Hospitality \& Leisure Marketing, 14, 47-68.

8. Global Luxury Hotel Market Analysis 2019 by Size, Share, Trends, Segmentation and Vendors, Industry Overview, Demand, Customer Behavior and Forecast 2024. Reuters (2019). Retrieved from https://www.reuters.com/brandfeatures/venture-capital/article?id=80660

9. Goteli v Ukrayini, jaki mozhut' dozvolyty sobi til'ky zamozhni turysty. Igotoshorld. Retrieved from https://ua.igotoshorld.com/ua/article/1271_samje-dorogieoteli-v-ukraine.htm

10. Khalid Saleh Al-rasheed. The Evaluation of Customers Services Quality in Five Star Hotels in the City of Riyadh.International Journal of Academic Research in Accounting, Finance and Management Sciences.Vol. 4(1), pp. 371-381, 2014.

11. Kuo, N. T., Chang, K. C., Cheng, Y. S., \& Lai, C. H. (2013). Investigating the effect of service quality on customer loyalty in the hotel industry: The mediating role of customer satisfaction and the moderating roles of service recovery and perceived value. Journal of China Tourism Research, 9, 257-276.10.1080/ 19388160.2013.812896

12. Luxury Hotel Market report. Retrieved from http://www.arcognizance. com/enquiry-sample/236034

13. Mukhles M Al-Ababneh. Service Quality in the Hospitality Industry. Journal of Tourism \& Hospitality. Al-Ababneh, J Tourism Hospit 2017, Volume. Issue 1. 
Retrieved from https://www.longdom.org/open-access/service-quality-in-thehospitality-industry-2167-0269-1000e133.pdf

14. Najafi S., Saati S., Tavana M. (2015). Data Envelopment Analysis in Service Quality Evaluation: An Empirical Study. Journal of Industrial Engineering International. V.11., P. 319-330.

15. Pokolenie Al'fa: kto oni i v chjom ih osobennosti. Reklamaster. Retrieved from https://reklamaster.com/marketing-and-advertising/pokolenie-alfa-kto-oni-i-vchjom-ih-osobennosti

16. Salszar A., Costa J., Rita P. (2010). A service quality evaluation scale for the hospitality sector: Dimensions, attributes and behavioural intentions, Worldwide Hospitality and Tourism Themes, Vol. 2 Issue: 4, pp.383-397. Retrieved from https://doi.org/10.1108/17554211011074047

17. Saving for travel is a priority for millennials: Here's how they save and spend. The Economic times. Retrieved from https://www. economictimes.indiatimes. com/articleshow $/ 63054924 . c m s$ ?utm_source $=$ contentofinterest\&utm_medium=text\&ut m_campaign $=$ cppst

18. Schulz von Thun, Friedemann. Miteinander reden, 1 Störungen und Klärungen, 2 Stile, Werte und Persönlichkeitsentwicklung, 3 Das innere Team und situationsgerechte Kommunikation. Retrieved from https://www.amazon.de/gp/ product $/ 3499624079 / \mathrm{ref}=$ as_li_qf_sp_asin_tl $? \mathrm{ie}=\mathrm{UTF} 8 \&$ camp $=1638 \&$ creative $=67$ $42 \&$ creative $\operatorname{SIN}=3499624079 \&$ linkCode $=$ as $2 \& \operatorname{tag}=$ javatechnolog -21

19. Sharma K., Sharma A. Evaluation of the Service Quality for Hotel Industry A Case Study. Advances in Computational Sciences and Technology, 2017. Volume 10, Number 6. P. 1615-1619. 